Measurable properties of

$\mathrm{Al}_{2} \mathrm{O}_{3}$ ceramic injection

\section{molding raw materials}

\author{
ÁDÁM EGÉSZ - GE Hungary Ltd., Budapest, Hungary - adam.egesz@ge.com \\ LÁszLó A. GÖMZE - Department of Ceramics and Silicate Engineering, University of Miskolc, Miskolc, \\ Hungary · femgomze@uni-miskolc.hu
}

Received: 11. 12. 2013. " Érkezett: 2013. 12. 11. " http://dx.doi.org/10.14382/epitoanyag-jsbcm.2013.20

\section{Abstract}

Powder injection molding (PIM), which encompasses metal injection molding (MIM) and ceramic injection molding (CIM), is a process which enables large scale production of complex-shaped components for use in a diverse range of industries. Ceramic injection molding (CIM) is a technology for manufacturing complex, precision, netshape components from ceramic powder. In the illuminant industry, for producing arc tube parts for high intensity discharge lamps the applied method is the ceramic injection molding. The ceramic arc tube parts are made of high purity alumina powder. By producing ceramic parts, one of the most critical steps is to optimize the injection molding process, to determine and control the influential machine parameters, which have an effect on the quality of the end product. Nevertheless, the properties of injection molding raw material is needed to be known before any optimization of the injection molding process, because later the molding process is optimized for this material, to decrease the amount of cracked ceramics.

For producing ceramic arc tube parts (plugs), there are two different major components used for producing injection molding raw material (feedstock): high purity alumina powder as the main component, and an organic paraffin wax as a binder material. It is expressly important to know the physical and dimensional properties of the alumina powder, since mainly these have affect on the homogeneity and viscosity of feedstock, and therefore on the quality of the end product. In the present research, both the main components and the moldable raw material were investigated by visual, physical, chemical and thermal methods. It was found - most importantly - that the viscosity of the raw material linearly decreases with the increasing grinding time of the alumina powder.

Applied analytical methods in terms of laser granulometry, tap density analysis, differential thermo-analysis and rheology analysis were used.

Keywords: alumina powder, paraffin wax, ceramic injection molding, laser granulometry, tap density, differential thermo-analysis, rheology analysis

\section{Introduction}

Powder injection molding (PIM) is a technology for manufacturing complex, precision, netshape components from either metal or ceramic powder. The potential of PIM lies in its ability to combine the design flexibility of plastic injection molding and the nearly unlimited choice of material offered by powder metallurgy, making it possible to combine multiple parts into a single one. Furthermore, PIM overcomes the dimensional and productivity limits of isostatic pressing and slip casting, the defects and tolerance limitations of investment casting, the mechanical strength of die-cast parts, and the shape limitation of traditional powder compacts $[1,2,10]$.

There are two different major components used for producing injection molding raw material (feedstock) in the illuminant industry for producing ceramic arc tube parts (plugs) for the High Intensity Discharge lamps: high purity alumina powder as the main component, and an organic paraffin wax as a binder material. The flow chart of injection molded ceramic parts production can be seen in Fig. 1 .

Producing the feedstock, the wax is heated in a sigma-blade mixer, and the alumina powder is sequentially added to the
Ádám Egész

Graduated in University of Miskolc, Department of Ceramics and Silicate Engineering as a material engineer, where he currently continues his studies as PhD student. He works at GE Lighting as project engineer, where he optimizes the manufacturing process of ceramic production for high intensity discharge lamps, especially the injection molding and its raw material. During his studies, he prepared several award-winning papers at Students' Scientific Workshops.

Prof. Dr. László A. Gömze Establisher (in July 1st, 1999) and head of Department of Ceramics and Silicate Engineering in the University of Miskolc, Hungary. Since then 7 students from the department have successfuly completed their PhD theses and 4 of them were managed by Prof. Gömze. Until today he is author of 2 patents, 4 books and more than 250 scientific papers. He was the chair of International Scientific Advisory Board of the international conferences ic-cmtp2 in 2012 and ic-rmm 1 in 2013. Recently, he is the chair of the International Organization Board of the 3rd International Conference ic-cmtp3 on Competitive Materials and Technological Processes.

molted wax material. The given, properly homogenized mixture is cooled down, and broke in jaw crusher to get granules from it. The granules can be used for the ceramic injection molding process (Fig. 2).

To know the physical, chemicaland thermalproperties of the given feedstock granules is absolutely necessary, if an efficient injection molding process is to be set up, which results a quality end product as well [3-6]. The most commonly occurring failures in the end product are the cracks, voids and different material discontinuities, and to avoid these failures, the best way is the qualification of raw materials.

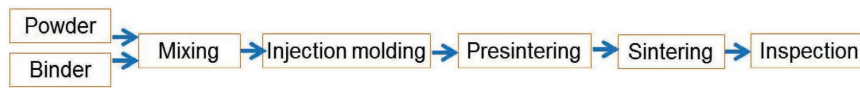

Fig. 1. Flow chart of injection molded ceramic production

1. ábra Kerámia fröccsöntés folyamatábrája

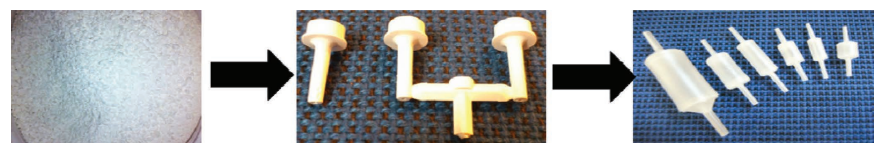

Fig. 2. Granules raw material, injection molded green-and end product (arc tube) 2. ábra Granulált alapanyag, félkész termék és késztermék (kisülöcsö)

\section{Experimental}

To qualify the alumina powder and feedstock raw material, the following measuring methods were tested: 


\subsection{Laser granulometry}

The laser granulometry method can be used to determine the grain size distribution of the usable powder, to qualify the alumina powder. Additionally to the grain size distribution, the grade of polydispersity (Fig. 3) and the compaction and volume filling properties of the powder can be determined and thus the density of the end product can be predestined $[5,6,8,9,11,12,22$ 24]. The principle of the measurement is the following: the intensity-distribution of monochromatic parallel light beam is measured in the function of the scattering angle, when it has been transmitted through the sample. From this value, using different models and theories, the grain size distribution of the particles can be counted in the sample $[7,10]$.

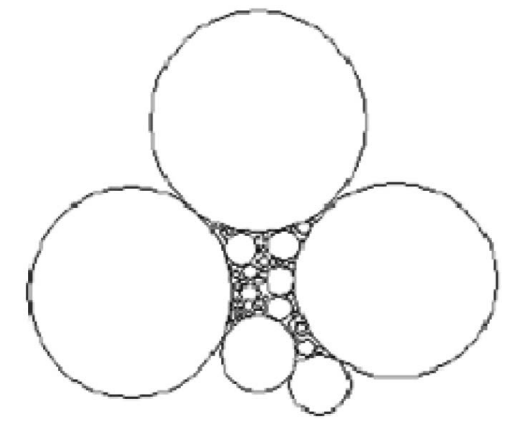

Fig. 3. Scheme of polydisperse alumina powder

3. ábra Polidiszperz alumínium-oxid por sémája

\subsection{Tap dendity measurement}

Tap density measurement can provide an alternative to the laser granulometry if do not have enough time and do not have opportunity to apply the relatively complicated and timeconsuming laser granulometry method. In this way, the density and the grade of polydispersity of the powder can be determined $[6,7,10]$. The principle of the tap density measurement is the following: the given weight of alumina powder is put into a scaled cylinder that is laid on a resonator unit. The unit shakes the cylinder at defined vibration rate (Fig. 4). The volume of the vibrated powder is recorded after the vibration, and the tap density can be calculated by dividing the weight of the powder with its volume. The tap density, and so the appropriate grain size distribution of the powder can be adjusted with grinding in vibratory ball mill [13-18,25-27].

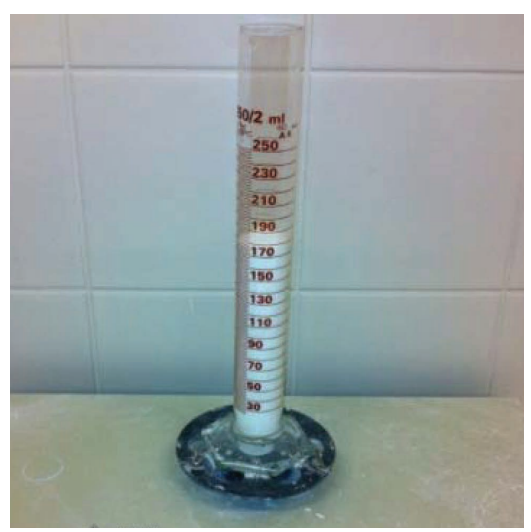

Fig. 4. Tap density measurement of alumina powder

4. ábra Alumínium-oxid por rázott sürüség mérése

\subsection{Differential thermo-analysis}

The effect of heat during endothermic and exothermic reactions in solid materials can be measured using the well known differential thermo-analysis method. The investigated material is heated together with a comparative material (inert material). In the inert material no any endothermic or exothermic process or any phase transformation occurs in the temperature range used. By comparison, the phase transformations - and corresponding temperatures - are determinable in different materials, e.g. melting, evaporation or ignition temperatures [19,20,21].

In the studied case, the most important is to know the injection molding work temperature of the used raw material, since the process have to be adjusted to the proper temperature; which is above the melting temperature, but it is under the intensive evaporation temperature, to avoid the material loss during the injection molding process.

\subsection{Rheological test}

By injection molding it is necessary to know the rheological properties and the behaviour of raw materials, especially the viscosity. Mainly, this property defines the behaviour of the material during injection molding, and identifies the flow behaviour in the molding tool, thus it can have effect on the quality of the end product [28-35].

To define the viscosity of feedstock, dynamic rotational rheometer and capillary rheometer were used.

Besides of the raw material, to know the rheological properties of wax binder material can be also important, since mainly the binder material defines the rheological behaviour and viscosity of injection molding raw material $[36,37,38]$.

\section{Results and discussion}

\subsection{Laser granulometry}

The first measurement to qualify the properties of the powder is the laser granulometry to investigate grain size distribution. The method is able to determinate the typical grain size and grain distribution of the alumina powder.

In the followings a comparison is given for a raw, unmilled and 10 minutes in vibration ball mill milled alumina powder. The grain distribution curve of unmilled powder can be seen in Fig. 5, where the two peaks on different grain sizes can be observed, which confirm the polydisperse grain size distribution mentioned earlier (Fig. 3).

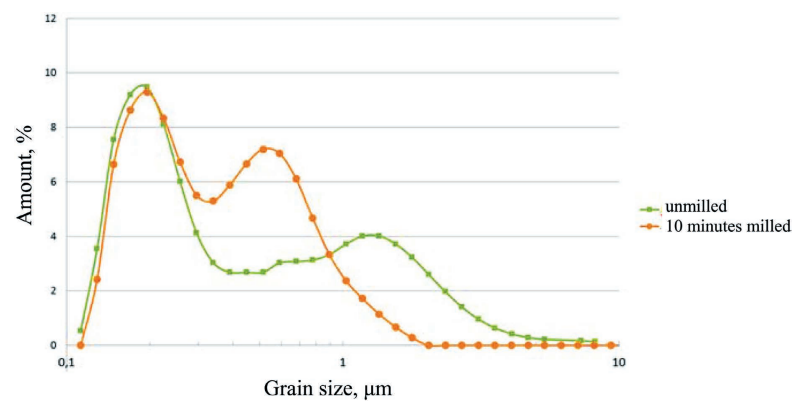

Fig. 5. Grain size distribution of unmilled and 10 minutes milled alumina powder 5. ábra Öröletlen és 10 percig örölt alumínium-oxid por szemcseméret-eloszlása 
The shape of the curve of the milled powder is clearly different (Fig. 5). It can be seen that the second peak is higher, but located closer to the first peak in the smallest grain size range, which indicates the presence of smaller particles and less pronounced polydisperse properties of the powder, but better compaction properties and higher density, due to the higher amount of small particles.

\subsection{Tap density measurements}

As it was mentioned earlier, the tap density and so the appropriate grain size distribution of the powder can be adjusted with grinding in vibratory ball mill.

In the experiment alumina powders with different initial grain size distributions were tested and grinded in vibratory ball mill. The initial average grain size was defined using laser granulometry. During the test the authors have applied different grinding times for the different powders. The tap density of the milled powders was determined after grinding.

The results of the experiment, the tap density of 4 powders with different initial grain sizes can be seen in Fig. 6. An exponential response can be found between the tap density and the grinding time since more small particles are produced during the grinding, which have better volume filling and compaction properties. The small particles can be wedged among the larger particles (polydisperse powder). It can be also realised that less grinding time is needed to get the same tap density if a powder with smaller initial grain size is used. It is in evidence that one can conclude from the measured tap density to the grain size of alumina powder.

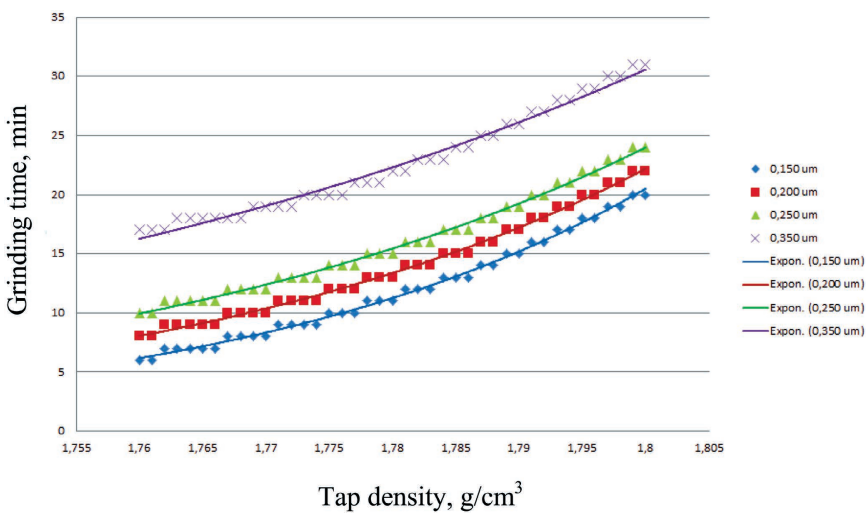

Fig. 6. Tap density of alumina powders vs. grinding time

6. ábra Aluminium-oxid porok rázott sürüségének és örölési idejének az összefüggése

\subsection{Differential thermo-analysis}

For the played out processes we can conclude from the weight changing of material. The feedstock material was experimentally tested by differential thermo-analysis and the graphical output can be seen in Fig. 7. The melting point $\left(\mathrm{T}_{\mathrm{m}}\right)$ on the first negative peak, the evaporation point $\left(\mathrm{T}_{\mathrm{e}}\right)$ on the first positive peak and the flashpoint $\left(\mathrm{T}_{\mathrm{f}}\right)$ on the second positive peak of the material on the DTA curve can be observed.

\subsection{Rheological test}

The rheological properties of raw material were investigated by a dynamic rotational rheometer to define the flow properties of the material at different temperatures and shear velocities. This measurement is important since the flow properties of the material has influence on the injection molding process, and thus on the quality of the end product. The recorded viscosity curves for the feedstock material can be seen in Fig. 8.

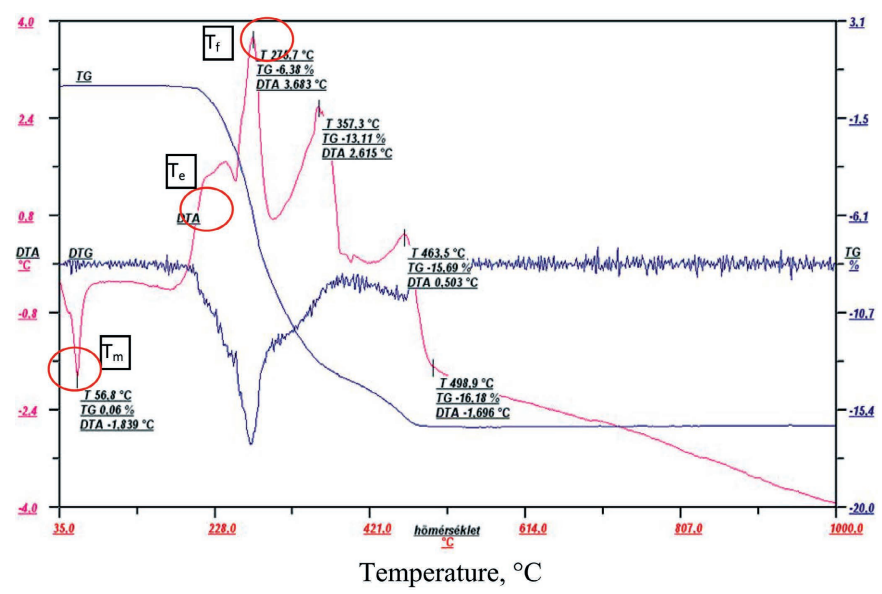

Fig. 7. Differential thermo-analysis of injection molding raw material 7. ábra Por fröccsöntési alapanyag derivatogramja

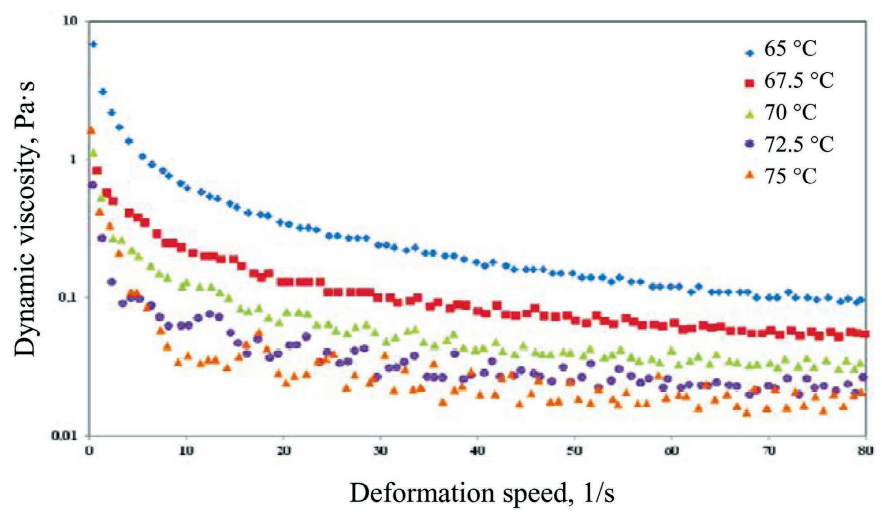

Fig. 8. Viscosity of injection molding raw material in the function of deformation speed and applied temperature

8. ábra Por fröccsöntési alapanyag viszkozitása a deformáció sebesség és a hömérséklet függvényében

It can be realised that the viscosity decreases exponentially with the increasing deformation speed, and decreases with the increasing temperature.

The viscosity of the raw material was investigated in the function of initial tap density and milling time of alumina powder as well. Alumina powders with different initial tap densities were milled for different periods of time and then the raw material was mixed from them with adding wax binder. The viscosities of the different raw materials were measured at constant temperature of $68^{\circ} \mathrm{C}$ by a capillary viscometer. The results of experiment can be seen in Fig. 9.

It can be concluded that the viscosity can be well adjusted with diversifying the milling time of the alumina powder, by given and constant mixing conditions, since the correlation is quasi linear between the milling time and viscosity, and the slope of the curves is quite similar. It can be observed that the viscosity of the different powder-made raw materials is decreasing with the increasing milling time. It is also visible that the powder with lower initial tap density needs to be 
milled for a longer time to prepare a raw material with a given viscosity. The explanation for this phenomenon can be that the tap density is increasing with the milling time and there are more grains in a given volume with higher specific surface area where the binder material can adhere. It can decrease the internal friction of the raw material.

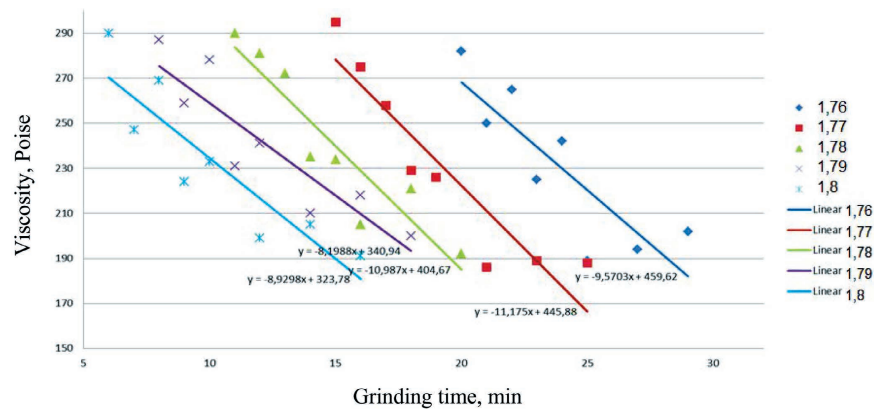

Fig. 9. Viscosity of injection molding raw materials with different initial tap density powder

9. ábra Por fröccsöntési alapanyagok viszkozitása eltérő rázott sürüség esetén

\section{Conclusions}

It was demonstrated that the investigated measuring methods are suitable to qualify either the alumina powder, or the mixed injection molding raw material. The quality of the raw materials can be determined by the proposed investigations and the classification can be possible before use.

It is possible to determine the grade of polydispersity of the alumina powder by laser granulometry. The grade of polydispersity can be reduced in the alumina powder using vibration ball mill to enhance the volume filling performance.

The tap density measurement can be a good supplementary investigation for the grain size and grain size distribution of alumina powder.

The injection molding raw material can be characterized by differential thermo-analysis: evaporation, melting and ignition point can be found and the temperature work point for injection molding can be determined.

The dynamic viscosity of the injection molding raw material decreases exponentially with the increasing deformation speed, and decreases with the increasing temperature. It was observed that the rheological behaviour of the raw material depends more on the applied temperature than on the deformation speed gradient.

The dynamic viscosity of the different powder-made raw materials is decreasing with the increasing milling time. Alumina powder with lower initial tap density needs to be milled for a longer time to prepare a raw material with a given viscosity.

\section{Acknowledgement}

The paper was published with the permission of ic-rmm1, the 1st International Conference on Rheology and Modeling of Materials, 7-11 October 2013, Miskolc-Lillafüred, Hungary.

\section{References}

[1] Mutsuddy, B. C.: Ceramic Injection Molding, Chapman and Hall, 1995, $368 \mathrm{p}$.
[2] Hausnerova, B. - Marcanikova, L.: Rheological Characterization of Powder Injection Moulding using Feedstock Based on Aluminium Oxide and Multicomponent Water-Soluble Polymer Binder. Proceedings of Recent Advances in Fluid Mechanics and Heat \& Mass Transfer, 2011, pp. 245-250.

[3] Krauss, V. A. - Pires, E. N. - Klein, A. N.: Rheological Properties of Alumina Injection Feedstocks. Materials Research, Vol. 8, No. 2, 2005, pp. 187-189. http://dx.doi.org/10.1590/S1516-14392005000200018

[4] Rak, Z. S.: New trends in powder injection moulding. Powder Metallurgy and Metal Ceramics, Vol. 38, No. 3-4, 1999 March-April, pp. 126-132. http://dx.doi.org/10.1007/BF02676037

[5] Stanimirovic, Z.: Injection Molded Mn-Zn Ferrite Ceramics. Proceedings of 27th International Conference on Microelectronics MIEL 2010, 2010, pp. 227-229. http://dx.doi.org/10.1109/MIEL.2010.5490493

[6] Wei, W. C. J. - Wu, R. Y. - Ho, S. J.: Effects of pressure parameters on alumina made by powder injection moulding. Journal of the European Ceramic Society, Vol. 20, No. 9, August 2000, pp. 1301-1310. http://dx.doi. org/10.1016/S0955-2219(99)00295-2

[7] Yin, H. Q. - Jia, C. C. - Qu, X. H.: Micro powder injection moldinglarge scale production technology for micro-sized components. Science in China Series E: Technological Sciences, Vol. 51, No. 2, 2008, pp. 121-126. http://dx.doi.org/10.1007/s11431-008-0023-y

[8] Kulkov, S. - Grigoriev, M.: Sintering of $\mathrm{Al}_{2} \mathrm{O}_{3}$ ceramics based on different sizes powders. Épitöanyag, Vol. 62, No. 3, 2010, pp. 66-69. http://dx.doi. org/10.14382/epitoanyag-jsbcm.2010.13

[9] Csányi, T. J. - Gömze, L. A.: Impact of nitrogen atmosphere on sintering of alumina ceramics. Építöanyag, Vol. 60, No. 1, 2008, pp. 15-18. http:// dx.doi.org/10.14382/epitoanyag-jsbcm.2008.4

[10] Gitzen, W. H.: Alumina as a ceramic material, The American Ceramic Society, Ohio, 1970, 264 p.

[11] Berecz, E.: Kémia múszakiaknak, Nemzeti Tankönyvkiadó, Budapest, 1991, 816 p.

[12] Bárczy, P.: Anyagszerkezettan, Miskolci Egyetem, 1998, 280 p.

[13] Messinig, G. L. - Mccauley, W. - Mazdiyasni, K. S. - Haber, R. A.: Advances in Ceramic, Ceramic Powder Science, The American Ceramic Society, 1987, Vol. 21

[14] Kok, M.: Production and mechanical properties of $\mathrm{Al}_{2} \mathrm{O}_{3}$ particlereinforced aliminum alloy composites. Journal of Materials Processing Technology, Vol. 161, No. 3, 30 April 2005, pp. 381-387. http://dx.doi. org/10.1016/j.jmatprotec.2004.07.068

[15] Sevik, H. - Kurnaz, S. C.: Properties of alumina particulate reinforced aluminium alloy produced by pressure die casting. Materials \& Design, Vol. 27, No. 8, 2006, pp. 676-683. http://dx.doi.org/10.1016/j. matdes.2005.01.006

[16] Filser, F. - Gauckler, L. J.: Keramische Werkstoffe, Kapitel 4: 4 Beispiele für strukturkeramische Werkstoffe, ETH-Zürich, Department of Materials, 2006

[17] Csányi, T. J.: Alumínium-oxid porkerámiák alakadási technológiai paramétereinek optimalizálása, különös tekintettel a mechanikai tulajdonságokra és a mikroszerkezetre, PhD Thesis, Miskolc, 2007

[18] Tisza, M.: Anyagvizsgálat, Miskolci Egyetemi Kiadó, 2001, 494 p.

[19] Sōmiya, S.: Handbook of Advanced Ceramics. Volume I: Materials Science. Amsterdam, Elsevier, 2003, 764 p.

[20] Tamás, F.: Szilikátipari laboratóriumi vizsgálatok, Müszaki Könyvkiadó, Budapest, 1970

[21] Enrique, J. E. - Ochandio, E. - Gazulla, M. F.: Chemical Analysis, in Engineered Materials Handbook, ASM International, Materials Park, $\mathrm{OH}$, 1991. Vol. 4

[22] Funk, J. E. - Dinger, D. R.: Particle Packing, Part 2. Review of Particle Packing of Polydisperse Particle System, Interceram, 1992. 41 (3), 176179.

[23] Stenger, F. - Mende, S.: Nanomilling in stirred media mills, Chemical Engineering Science, Vol. 60, No. 16, August 2005, pp. 4557-4565. http:// dx.doi.org/10.1016/j.ces.2005.02.057

[24] Peukert, W.: Material properties in fine grinding, International Journal of Mineral Processing, Vol. 74, Supplement, 10 December 2004, pp. S3-S17. http://dx.doi.org/10.1016/j.minpro.2004.08.006 
[25] Barth, H.: Modern Methods of Particle Size Analysis, Wiley-Interscience, New York, 1985, 320 p.

[26] Allen, T.: Particle Size Measurement, Wiley-Interscience, New York, 1981, $552 \mathrm{p}$.

[27] Serkowski, S. - Müller, M.: Vacuum granulation of ceramic powders - Device and ability, Journal of Materials processing Technology, Vol. 175, No. 1-3, 1 June 2006, pp. 382-386. http://dx.doi.org/10.1016/j. jmatprotec.2005.04.065

[28] Sathyjakumar, M. - Gnanam, F. D.: Influence of additives on density, microstructure and mechanical properties of alumina, Journal of Materials Processing Technology, Vol. 133, No. 3, 20 February 2003, pp. 282-286. http://dx.doi.org/10.1016/S0924-0136(02)00956-1

[29] Lowell, S. - Shields, J.: Powder Surface Area and Porosity, Chapman and Hall, New York, 1984, 250 p.

[30] Nivot, C. - Valdivieso, F. - Goeuriot, P.: Nitrogen pressure effects on non-isothermal alumina sintering, Journal of the European Ceramic Society, Vol, 26, No. 1-2, 2006, pp. 9-15. http://dx.doi.org/10.1016/j. jeurceramsoc.2004.10.006

[31] Cótica, L. F. - Paesano, A. Jr. - Zanatta, S. C. - de Medeiros, S. N. - da Cunha, J. B. M.: High-energy ball-milled $\left(\alpha \mathrm{Fe}_{2} \mathrm{O}_{3}\right)\left(\alpha \mathrm{Al}_{2} \mathrm{O}_{3}\right)$ system: A study on milling time effects, Journal of Alloys and Compounds, Vol. 413, No. 1-2, 9 March 2006, pp. 265-272. http://dx.doi.org/10.1016/j. jallcom.2005.05.046

[32] Mutsuddy, B. C.: Influence of Powder Characteristics on the Reology of Ceramic Injection Molding Mixtures, Fabrication Sci., 3, Proceedings of the British Ceramic Society, 1983. pp. 117-137.

[33] Mamata P. - Parag B.: Influence of Sucrose Addition on Rheology of Alumina Slurries Dispersed with a Polyacrylate Dispersant, Journal of the American Ceramic Society, Vol. 88, No. 4, April 2005, pp. 833-838. http:// dx.doi.org/10.1111/j.1551-2916.2005.00183.x

[34] Bruni, G. - Lettieri, P. D.: An investigation of the effect of the interparticle forces ont he fluidization behaviour of fine powders linked with rheological studies, Chemical Engineering Science, Vol. 62, No. 1-2, January 2007, pp. 387-396. http://dx.doi.org/10.1016/j.ces.2006.08.059

[35] Edirisinghe, M. J. - Evans J. R. G.: Rheology of Ceramic Injection Molding Formulations, British Ceramic Transactions, Vol. 86, No. 1, 1987, pp. 1822.

[36] Tanaka, T. - Saitoh, K. - Satoh, M. - Miyazaki, M. - Kaneko, Y.: Injection Molding of Alumina, Yogyo-Kyokai-shi, Journal of the Ceramic Association, Japan Vol. 93 (1985) No. 1081, pp. 572-576. http://dx.doi.org/10.2109/ jcersj1950.93.1081_572

[37] Cima, M. J. - Lewis, J. A.: Binder Distribution in Ceramic Greenware during Thermolysis, Journal of the American Ceramic Society, Vol. 72, No. 7, July 1989, pp. 1192-1199. http://dx.doi.org/10.1111/j.1151-2916.1989. tb09707.x
[38] Csányi, J.: Rheological characteristics of alumina powders in dry pressing technology. Építőanyag, Vol. 61, No. 1, 2009, pp. 6-10. http://dx.doi. org/10.14382/epitoanyag-jsbcm.2009.2

\section{Ref.:}

Âdám Egész - László A. Gömze: Measurable properties of $\mathrm{Al}_{2} \mathrm{O}_{3}$ ceramic injection molding raw materials

Épitőanyag, 65. évf. 4. szám (2013), 107-111. p. http://dx.doi.org/10.14382/epitoanyag-jsbcm.2013.20

$\mathrm{Al}_{2} \mathrm{O}_{3}$ kerámia fröccsöntés alapanyagának vizsgálatai A por fröccsöntés - amely magában foglalja a fém fröccsöntést és a kerámia fröccsöntést is - olyan folyamat, amely lehetôvé teszi bonyolult, összetett geometriájú termékek alakadását nagy darabszámban az ipar számos ágazata számára. Kerámia fröccsöntéssel komplex, precíziós termékek állíthatók elố kerámiapor felhasználásával. A fényforrásiparban a kisülőlámpák kerámia alkatrészeinek alakadása fröccsöntéssel történik. A kerámia kisülốcsôalkatrészek alapanyaga nagytisztaságú alumínium-oxid por. Az alkatrészek elóállításánál a legkritikusabb folyamatlépés a fröccsöntés, ezért optimalizálni, szabályozni szükséges azon paramétereit, melyek hatással lehetnek a végtermék minôségére. Ehhez meg kell ismernünk a felhasználandó fröccsöntési alapanyag tulajdonságait, kritikus paramétereit, hogy ezeket szabályozva egy robosztusabb fröccsöntési folyamatot állíthassunk be. A kerámia alkatrészek gyártásához a fröccsöntési alapanyagnak két fố alkotója van: nagytisztaságú alumínium-oxid por és paraffin viasz kötôanyag. Különösen fontos, hogy ismerjük az alumíniumoxid por fizikai, kémiai és morfológiai tulajdonságait, mert fốként ezek vannak hatással az elkészített fröccsöntési alapanyag homogenitására, viszkozitására, és igy a végtermék minôségére. Jelen tanulmányban a fröccsöntési alapanyag, valamint annak mindkét alkotóeleme tulajdonságait vizsgáltuk vizuális, fizikai, kémiai és termikus elemzési módszerekkel. A vizsgálatok alapján legfontosabb megállapításként elmondható, hogy a fröccsöntési alapanyag viszkozitása lineárisan csökken az alumínium-oxid por ôrlési idejének növelésével. Az alkalmazott vizsgálati módszerek a lézer granulometria, a rázott sûrūségmérés, a differenciál termoanalízis és a reológiai analízis voltak.

Kulcsszavak: alumínium-oxid por, paraffin wax, kerámia fröccsöntés, lézer granulometria, reológia, rázott súrúség

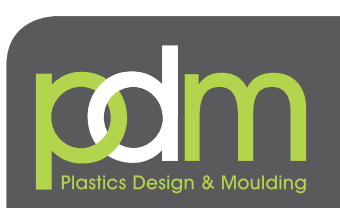

Plastics Design and Moulding (pdm) 2014 returns to the

Telford International Centre on 18-19 June 2014

and will be co-located with launch event -

Plastics Recycling Expo (pre), the only dedicated

plastics recycling exhibition and conference in Europe.

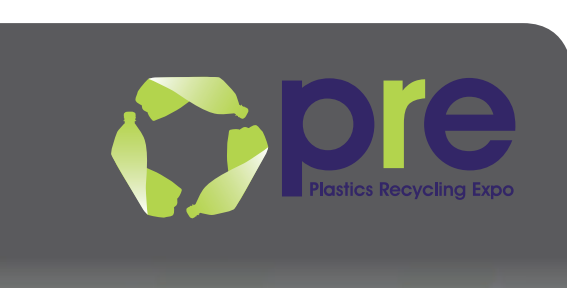

\section{About PDM}

Supported by the industry's major associations and key companies,

PDM is the only exhibition and conference specifically aimed at the design and moulding aspects of the UK's plastics sector. PDM attracts a high level, targeted audience which is relevant to your business and provides an unrivalled opportunity to meet new leads, identify business opportunities and build your market network.

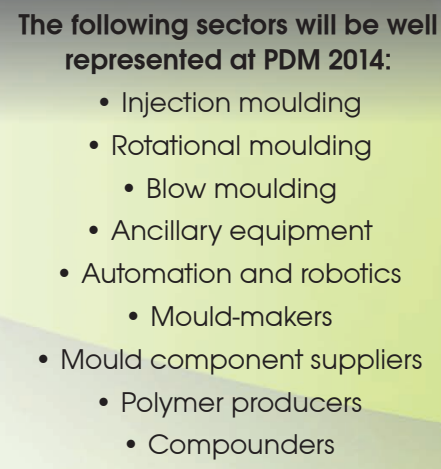

The following sectors will be well represented at PDM 2014:

- Injection moulding

- Rotational moulding

- Blow moulding

- Ancillary equipment

- Automation and robotics

- Mould-makers

- Mould component suppliers

- Polymer producers

- Compounders

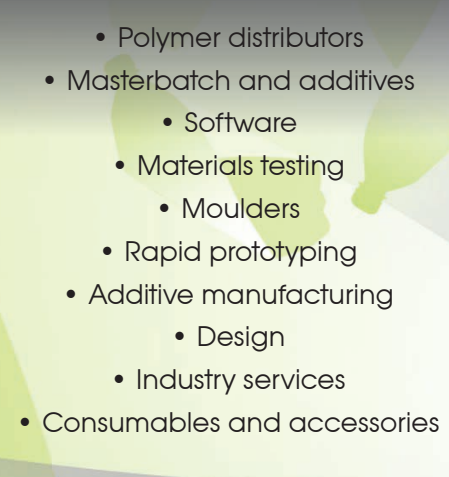

